American Research Journal of Humanities and Social Sciences

(ARJHSS)

ISSN (Online) : 2378-7031

Volume 2, 2016, 1-8 pages

AMERICAN RESEARCH JOURNALS

An Academic Publishing Franse

DOI: 10.21694/2378-7031.16003

\title{
The Voice of Indian Women Novelists and their Status in the Contemporary Indian English Literature -A Critical Study
}

\author{
Dr. Venkateswarlu Yesapogu, M.A., M.Phil, PhD. \\ Head, Dept of English, Principal FAC in V.V. \&M Degree College, Ongole, Prakasam D.T., A.P, India \\ Yvghosh.yvghosh@gmail.com
}

\begin{abstract}
Feminist writings were of crucial interest to the Post-colonial discourse for two major reasons. First, both patriarchy and imperialism could be seen to exert different forms of domination over those subordinate to them. Because of this, it was important for the experiences of women under the patriarchal influence to come out to the forefront and expose the undue cruelty be held on them by men. It was necessary for the women to oppose this male dominance over them. We observe that women continued to define the borders of the community, class and race. They tried to exert feminism through their works. Though the Indian women writers try to depict the women as strong and focused in their vision to succeed in lives, they were, however, ablest to succeed in their lives only in the space allotted to them by the men.

However, the Feminist writers tried to stamp their authority in a male dominated environment as best as it is possible to them. It was a very difficult path, as the women had to break through years of male dominance, taboos and beliefs that had heavily impregnated the society. In addition, critics argued that colonialism operated very differently for women and for men. This was so because women were subjected to both general discrimination as colonial subjects and specific discrimination as women addressed as 'double colonization.
\end{abstract}

Keywords: Male dominated society, discrimination, harassed, feminism, and status of woman

\section{INTRODUCTION}

Indian women writers in English have made the most significant contribution in the field of the English novel. Indian novel has grown considerably in bulk variety, and maturity. The development of Indian novel follows certain definite patterns, and it is not difficult to trace its gradual progression from the imitative stage to the realistic to the Psychological to the experimental stage. In the growth and development of Indian English novel, the 1980s occupy a unique position. During this period, some very promising women novelists published their first works. Some old masters also came out with works, which show that their creative powers have been intact all along. It is during the eighties that Indian women novelists earned unheard of honours and distinctions not only in India but also in abroad. The works by these Indian women novelists, like third generation women novelists, speak eloquently about their originality and unprecedented inventiveness.

Indian English literature is now a reality, which cannot be ignored. During the recent decades, it has attracted a widespread interest both in India and abroad. What began as a "hot-house plant" has now attained a luxuriant growth, branching off in several directions. The Indian women writers have made the most remarkable contribution to the sphere of fiction, which as Mulk Raj Anand says, has "come to stay as part of world literature." An idea of the true potential of this form of literature in India can be had by comparing the early novels by Indians with the recent arrivals in the same field of literary creation.

However, Indian writing in English in the Contemporary literary Scenario enjoys equal status with the literatures of the other Countries. Especially Indian women writers have made their voice heard around the World in the 
Indian way, expressing too artistically. Moreover, Indian women Writers in English too in the recent times have managed to excel in all areas of literature and achieved global recognition.

The Indian women writers expressed the role and position of woman through their writings in English, have enlightened the literature with its quality and vividness. Truly, it represented the culture, history, and all the variants necessary for the enrichment of the literature worldwide. In fact, India is the third largest producer of the novels after USA and UK. Although the writings profoundly deal with regionalism, they crossed the natural boundaries with universal themes. India is the land of diversity with so many languages, religions, races, and cultures. This multiplicity gave the writers an enormous liberty to deal with various themes. The voice of Indian women writers also dealt with historical, cultural, philosophical and much more basing their themes around mankind. The Indian women writers have concentrated their themes around sociological, Diasporic elements, feminine subjects, science and technologies, explorative writings, and much more.

The Indian women have significantly contributed to the overall world literature as equal with men writers. This contribution of India has been chiefly through the Indian writing in English, novelists being in the forefront in this respect. A number of novelists on the contemporary scene have given expression to their creative urge in no other language than English and have brought credit to the Indian English fiction as a distinctive force in the world fiction. To attempt creative expression on a national scale in an alien medium has seldom happened in human history, and it speaks of the prolific quality of the Indian mind to assimilate the newly confronting situations and the complex dilemmas of modern World. The new English fiction exhibits confidence in tackling new themes and experiments with new techniques and approaches to handle these themes. The novelists come to their task without any preconceived notions of what constitutes literary content. This encourages them to focus on a vast and comprehensive canvas and to invest their themes with epic dimensions.

All these Indian women writers could compete with best in the World, perhaps that best in their own right: "It would be no exaggeration to say that the best English fiction in the World is being written by the Indian women writers or those of Indian origin"(1992:21-22).

As far as Indian literature is concerned, it has perhaps been easier for these women novelists to reflect the new challenges and changes because of the simple fact that its vehicle itself is a globalised language. Again, the writers of the new fiction have mostly been a part of the Indian diaspora. Living in the west, and using English almost like a mother tongue, they have been thoroughly exposed to significant modern western literary movements like Post-Modernism, and to various narrative techniques like magic realism. This has enabled them to give a fresh orientation to fiction. At the same time, the best of them continue to have strong roots in India, so that they remain true to the kindred points of India and the west.

It is significant that the spirit of the age is more pervasively and effectively reflected in the Indian woman's fiction than in other forms like poetry and drama. The novel, by its very nature, is better equipped to deal with social reality, whatever, liberties it may take in projecting it. It is hardly surprising therefore that the most substantial contribution of the period comes from the Indian women writings of the fiction.

The voice of new Indian women writers through their writings, published in between 1980s and 1990s, has ushered in a literary renaissance is the third generation of women Indian English writers like Nayantara Sehgal, Anitha Desai, Arundhati Roy, Shashi Desh Pande, Gita Mehta, Bharathi Mukherjee, and Jhumpha Lahiri. These are the fore- most third generation women novelists and who hold centrality in the contemporary literary Scenario. They have made a distinct mark on the World literary scene with their rich cultural heritage and skilled language control. They have received national and International recognition, fabulous royalties and prestigious awards.

Among these Indian women novelists, the most talented are: Nayantara Sehgal, Anitha Desai, Arundhati Roy, Shashi Desh Pande, Gita Mehta, Bharathi Mukherjee, and Jhumpha Lahiri are according to these women 
novelists, as Anthony Spaeth has pointed out, are making conscious efforts to redefine English prose "with myths, humour or themes as vast as the subcontinent." Moreover, Sehgal heself once told in an interview in 1982: "I think we (women writers) are in a position to conquer English literature," (Ibid, 1989:552) and this is what precisely these novelists are trying to do in their own ways. Thus, they demand a serious critical attention, analysis, classification and, finally, definition as a distinct genre of fictional literature of our times.

The works of these women novelists have been accorded genuine recognition in India also. For example, no less than five novels were found worthy of the Sahitya Akademi Award - the greatest literary honour of the country during the 1980s itself. These are: Shashi Deshpande's That Long Silence and the woman novelist Nayantara Sahgal's Rich Like Us is one among them. These facts, which are only illustrative and by no means exhaustive, clearly show that Indian English novel has been given proper response and recognition inside India and abroad.

On par with great Indian male novelists, the contribution of women novelists is immensely significant. A number of women novelists have debut in the nineties. Their first novels are quiet effective in revealing the true state of Indian Society when it comes to the treatment of women. All these writers were born after Indian Independence, and English does not have any colonial associations for them. Their work is marked by an impressive feel for language and completely authentic presentation of contemporary India, with all its regional variations. They generally wrote about the urban middle class, the stratum of society they know best.

There are many women writers both novelists and poets, based in the USA and Britain. Some like Jhabvala and Anita Desai are late immigrants while others, like Jhumpa Lahiri belongs to the second generation of Indians abroad. Most expatriate writers have a weak grasp of actual conditions in contemporary India, and tend to recreate it through the lens of nostalgia. Their best works deal with Indian immigrants, the section of society they know at first hand. Sunithi Nam Joshi, Chitra Benerji, Divakarvas and Bharathi Mukherjee are the oldest, and naturally, the most prolific.

Writers like Jumpha Lahari, Manju Kapoor, Kiran Desai, and Arundhati Roy too have written novels of Magic Realism, Social Realism and Regional fiction, and benefited from the increasing attention that this fiction has received National and International awards. They have probed into human relationships, since the present problem is closely concerned with mind and heart and the crusade is against age-old established systems. In order to make the process of changes smooth and really meaningful, women writers have taken upon themselves this great task.

Away from this line of writing the lives of women, the most successful of the Indian women writers is Jhumpa Lahiri who created the difference among all the women writers. She is a dazzling storyteller with a distinctive voice. She is different from other Indian writers writing in English. Most of the first generation writers of Indian fiction are born and brought up in India. But Jhumpa Lahiri's connection with India is through her parents and grand parents. India would appear to her sometimes full of wonders, sometimes full of beggars. Moreover, the writers who live outside comment confidently on economic social and political scenario may appear very often exaggerating or understanding. However, Lahari is honest and authentic to her experiences.

For Lahiri "Every visit was an emotional see-saw across continents and cultures" (204). Lahiri is an Indian by ancestry, British by birth, American by immigration. She targets the Western audience by deliberately portraying the Indian American life. She also admits, "I learnt to observethings as an outsider and yet I knew that as different Calcutta is from Rhode Island, I belonged there in some fundamental way, in the way, I didn't seem to belong in the U.S." (The Times of India, 13 April 2000). This sense of freedom is one of the greatest thrills of writing fiction for her and she discovered her authorial freedom by publishing her debut book i.e. Interpreter of Maladies (1999) her debut anthology is collected stories that deal with the question of identity. 
Her another famous novel The Namesake (2003) which is essentially a story about life in the United States. But Lahiri says that Namesake deals with Indian immigrants in the United States as well as their children. For instance, though she is much more American than her parents she inherited a sense of exile from her parents. After her Ph.D. in Renaissance studies from Boston University, she had planned to write about her roots and origin. It appears "She is more American than her parents through her characters move constantly between two worlds grappling bravely with this cultural displacement" (The Times of India, April 7, 2000).

Anitha Desai is the best known of the contemporary women writers. Of all the contemporary novelists, she is indisputably the most popular and powerful novelist. She has made commendable contribution to the Indian English fiction. She is a novelist of urban milieu and is a fine mixture of Indian European and American sensibilities. She is essentially a psychological novelist. She claims that her novels are not reflection of Indian society or character. She does not reflect on social issues in her works like Mulk Raj Anand. She sees social realities from a psychological point of view and does not look at them as a social intimate expression of the inner world of her characters. She makes each of her work a haunting exploration of the psychic self. Her last novel Baumgartner's Bombay, written at Griton College, Cambridge, was published in 1988. In the nineties, she has not published any novel as yet. Thus, she has double sensibility, which gives her novels an objective effect. She however traveled widely in almost all the parts of India and her experiences of different sort of people and places have enriched her writing. Moreover, the same is true of Nayantara Sahgal, whose last novel Plans for Departure, published at the turn of the decade got her the Sahitya Academi Award.

The novelist with the most sustained achievement is Shashi Desh Pande who is labeled as feminist novelist succeeded in depicting the plight of a successful educated woman and problems of being a woman. She has written eight novels, six collections of short stories, and four children's books. Her popular novel The Dark Holds No Terror (1980) portrayed the life of a woman who marries a doctor and becomes the victim of brutalization. It is a story of courage and perseverance that she developed from within herself to break loose of society's traditional norms to gain her individuality and freedom. She has achieved tremendous amount of popularity through her writings. She depicts the Indian middle class mentality in all her novels. Her protagonist emerges from cultural rootedness in middle class Indian Society. Desh Pande generally has the heroine as the narrator and employs a kind of stream - of - consciousness technique. In another novel Roots \& Shadows (1983), we are introduced to another rebellious woman who refuses to accept traditional family life and escapes to the city to work. She later marries a man of her own choice. As time goes by, she realizes that life in the city is no different from the village. Almost all her novels deal with a crisis in the heroines' life. Her work is women-oriented, but it would not be correct to term her a feminist, as she consistently regates with the feminist identity. She simply portrays, in depth the meaning of being women in modern India.

Shashi Desh Pande's novel That Long Silence (1988) is viewed as her emergence as a major novelist. This novel won her the Sahitya Academe award for 1990, tells the story of an Indian housewife Jaya, an upper-middle class house wife who maintained her silence in Bombay throughout her life in the face of hardships that threaten to break it. The lack of depth in a woman's life is clearly depicted in this novel. She however, shows us that most of the family rules like the idea of trying to secure one's life by marrying a wealthy man and establishing a name in society by sending children to good schools, is shown how mundane, meaningless and mechanical a woman's life really is partly self-imposed by women themselves. In another novel A Matter of Time (1996), attempts to depict three generations of female human relationships. In her latest novel Small Remedies (2000), as we read this novel, we realize her over possessive attitude. This is a novel that dwells into the various aspects of motherhood. At last, Her, The Binding Vine, compels one to discover how the 'binding vine' of human emotions links and sustains diverse human beings as they go through life. 
Manju Kapoor is also one of the significant writers whose work establishes the nexus between the tradition and modernity. The dominating works of Kapoor can be critically seen in her significant novel Difficult Daughters (1998), which is her first novel. It was awarded Commonwealth Writers Prize for best first book, which has earned her very substantial success both commercially and critically. The novel Difficult Daughters which has been well received by one and all. The story of this novel is set around the time of partition, which is the story of a woman whose battle for Independence engulfs. Her second novel, A Married Woman (2003) which is a quite powerful as its predecessor and thematically even more controversial. But the novel proving Indian and universal achievement.

In the similar fashion, Bharati Mukherjee's fame has shot up in the recent years as an Indian American writer. Her novels Wife, Jasmine, The Holder of the World, Leave It To Me and Desirable Daughters make a bold attempt to rewrite the origins of America's history in the light of wider American experience. For instance her second novel Wife (1975), she writes about a woman named Dimple, who suppressed by men attempts to be the ideal Bengali wife, but out of fear and personal instability murders her husband. Her best fiction Jasmine (1989) develops the idea of the synthesis of the East and West with a story telling of young Hindu women, who leaves India for U.S. after her husband's murder as an illegal immigrant. Her fourth novel, The Holder of the World (1993), attempts to integrate contemporary travelogue and ancient history. This novel too has the theme of transformation and migration, but with a difference. Her fifth novel Leave It To Me (1997) is completely American. The only Indian touch is the prologue, which retells the mythological story of is the goddess, who killed the Buffalo Demon. This book is soaked in blood and reeks in violence. Her last and sixth novel is Desirable Daughters (2002) which acts as a bridge between transformation and migration and piles up meticulous details in the information. However, Bharati Mukherjee recaptures history in the most aesthetic sense. She continues writing about the immigrant experience in the most of her stories like in The Middle Man and Other Stories, a collection of short stories, which won her the National Book Critics Circle Award.

Gita Mehta is also another woman writer who proclaimed about the problems of the contemporary immigrant women with sublime standards. She wrote Snakes and Ladders and Glimpses of Modern India in 1997. It has become most widely read book particularly by those unfamiliar with India. In an interview, she said that her intention was "to make modern India accessible to westerns and to a whole generation who have no idea what happened before they were born" (24) (An Interview with C.J.S.Wallia). Gita Mehta's first novel is Raj (1989) which is a very powerful and enlighting readable novel. It is considered to be one of the great historical novels of our time. Raj is the story of the Maharani Jaya Singh, as well as the drama of India's struggle for Independence. However, Mehta's unique nature is to collect the richness of living is this rarity of perspective that gives her a witty ability to define her vision for India by her novels.

Arundhati Roy is the luminary among the contemporary women writers. She is one of the women writers who wrote about the plights of the downtrodden and the suppression of women in a male dominated world and the influence of Marxism on the lives of the downtrodden. When women writers maintained their reservations in offering a critical evaluation of Indian politics, Arundhati Roy emerged as a beacon of light to guide the Indian women writers. She has got overwhelming reception with The God of small things (1997), which has put her in the forefront of all the other writers. Her success with just the publication of her single book has already placed her on equal terms with Salman Rushdie and others. Moreover, She has surpassed even Vikram Seth's A Suitable Boy. The characters are entirely imaginary, with no factual correspondence to real life characters. Arundhati Roy mentions the Veteran Marxist E.M.S Namboodaripad by name, but proceeds to invent fictions about him, which led to widespread protests in Kerala, the state where he headed the first elected communist Government in world history. It is also a comprehensive protest novel, which describes atrocities against the powerless, children, women and untouchables. 
Arundhati Roy is the only novelist, who being an activist, is constantly writing about social problems. Her monograph, The Greater Common Good (1999) which reveals the truth about the Narmada Project. The book also shows her talent as an essayist and social reformer. Her earlier essay The End of Imagination (1998) which urged nuclear disarmament. She is the winner of Booker Prize as well as the Sidney Peace Prize. These Feminist writers tried to stamp their authority in a male dominated environment as best as it is possible to them. It was a very difficult path, as the women had to break through years of male dominance, taboos and beliefs that had heavily impregnated the society. In addition, critics argued that colonialism operated very differently for women and for men. This was so because women were subjected to both general discrimination as colonial subjects and specific discrimination as women addressed as 'double colonization.'It is from these perceptions one should view the contribution of women writers of the nineties like Anita Desai, Shashi Deshpande, Gita Mehta, Gita Hariharan, Bharati Mukherjee, Uma Vasudev and Arundhati Roy. Undoubtedly, it is understood that they have perceived a good job in exposing the fallacies of the male -dominated society and letting the public beware of the various atrocities heaped upon women who dared to cross the various rigid boundaries that were laid on them by society. The debate in several colonized societies over the deleterious effects of gender or colonial oppression on women's lives continues to hold its significance in the analysis of the society. Feminism, like post Colonialism, is concerned with the ways to which representation and language were crucial in order to identify the formation and construction of subjectivity. Both for the patriarchal as well as the matriarchal community, language was crucial in order to identify formation and for the construction of subjectivity. Language subverts patriarchal power and brings more authentic forms for negotiating gender equality.

In a totally male dominated environment, it was a major effort for the women writers to expose what society called as the mechanics of patriarchy. To fight against the cultural a mind set in men and women, one of the first things that these women writers did was to make their writings more eclectic. They began to write based on the findings and writings of other criticisms. This is vividly presented in these novels. Secondly, instead of attacking the male version of writing, they now decided to explore the nature the feminine world by trying to reconstruct the world of suppressed emotions. Lastly, attention was given to the need to bring about a new game of women's writing in a way that, previously neglected women writers were now given new prominence. Another critical issue that was handled by these women writers was the issue of 'Style in language'. It was Jane Austin who devised a technique for writing that was perfectly natural, elegant and proper for the use of women writers. Women could now write in clauses that were linked in loose sequences, rather than balanced and patterned as used by male writers.

\section{CONCLUSION}

Thus, the feminist Criticism was the direct product of the Women's movement of 1916. Because Feminism has become a vital aspect in literature in contemporary society and the female perspective, expressed through women's writing of all kinds is considered to be more than a valuable connective to an all male view of the universe. In exploring the question what is it to be woman lie the history of mankind: "History of mankind is the history of repeated injuries and usurpations on the part of man towards woman having indirect object the establishment of an absolute tyranny over her."(10) (Declaration of Sentiments and Resolutions of the First Women's Rights Convention In America, Seneca Falls, 1848). It is perceived that the very subjection of women is consolidated by religion. The Holy Bible holds such observations and perceptions: "Wives submit yourselves to your husbands as to the Lord. (Ephesians, 5:22) The Holy Bible). This concept of women consolidated by Christianity affected their status for centuries. Gradually women lost the right to control their lives and as a result, they were deprived not only of human rights but also of humanity. 
Literacy spread rapidly and women began to utilize the power of the pen. Betty Frieday, the mother of Modern Feminism with the publication of Feminine Mystique (1963) initiated this new change. The new women's movement expanded into a commanding political force. "Women are an oppressed class ... We are exploited as sex objects" (42).

It is from these perceptions one should view the contribution of women writers of the nineties like Anita Desai, Shashi Deshpande, Gita Mehta, Gita Hariharan, Bharati Mukherjee, Uma Vasudev and Arundhati Roy. Undoubtedly, it is understood that they have perceived a good job in exposing the fallacies of the male -dominated society and letting the public beware of the various atrocities heaped upon women who dared to cross the various rigid boundaries that were laid on them by society.

\section{REFERENCES}

Asnani, Shyam. New Dimensions of Indian English Novel. Delhi: Doaba House, 1987. Print.

Betty, Frieday. The Feminine Mystique. New York. Dell, 1963. Print.

Desai, Anita. Baumgartner's Bombay, London: Penguin, 1989. Print.

Deshpande, Shashi. That Long Silence, New Delhi: Penguin India, 1989. Print.

Gilbert, Sandra, M. and Susan Gubar. "The Mad Woman in the Attic: The Woman Writer and the Nineteenth century Imagination." New Haven: Yale University Press, 1984. Print.

Indian Women Novelists. Set III, Vol.4. New Delhi. Prestige books. 1995. Print.

Kirpal, Viney. The New Indian Novel in English: A Study of the 1980s. New Delhi: Allied Publishers Ltd., 1990. Print.

Mukherjee, Bharathi. Wife. New York: Houghton, 1975. Print.

------ Jasmine. New Delhi: Penguin, 1990. Print.

Mukherjee, Meenakshi. 'The Perishable Empire: Essays on Indian Writing in English New Delhi: Oxford University Press. 2000. Print.

Naik, M.K. A History of Indian English Literature. New Delhi: Sahitya Akademi. 1982. Print.

....... Indian English Literature 1980-2000: A Critical Survey.Delhi: Pencraft International. 2001. Print.

Parker, Peter. 'The Sunday Times review,' literary Kolkata; Aug.25, 2002. Print.

Papastergiadis, Nikos. The Turbulence of Migration. Cambridge: Polity Press, 2000. Print.

Paranjape, Makarand R. In Diaspora: Theories, Histories, Texts New Delhi: Indialog Publications, 2001. Print.

Peterson, Kirsten Holst. And Anna Rutherford: 'Double colonization' in A Double Colonization, Colonial and Post-Colonial Women's Writing. 1986. Print.

Reddy, Sheela. 'Writing Through Turmoil'. Outlook, New Delhi,19 August 2002. Print.

Roy, Arundhati.. The God of Small Things. New Delhi: IndiaInk. 1997. Print.

Robison, Lillian. In her work Sex, Class and Culture. 1978. Print.Rushdie, Salman. Mirrorwork: 50 Years of Indian Writing, 1947-1997 New York: H. Holt, 1997. Print.

Sahgal, Nayantara. Plans for Departure 1989. Print. 


\section{AUTHOR's BIOGRAPHY}

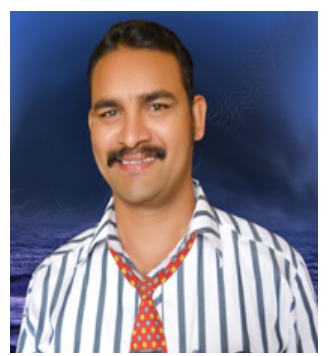

Dr. Venkateswarlu Yesapogu awarded his $\mathrm{PhD}$ degree in the contemporary Indian fiction at the Acharya Nagarjuna University, GUNTUR, Andhra Pradesh, India, his M.A., M.Phil, also happened in the English literature. He is now teaching English Literature and Phonetics in V.V. \&M. Degree College. He became the youngest Principal FAC by virtue of seniority among existing staff since 2009. His teaching is on main research interests including teaching of Phonetic Science as well as communication skills. He has recently published two books. The first entitled "The Fictional World of Amitav Ghosh" with ISBN 9789382186397; the second entitled "The Feminist Perspective in Amitav Ghosh's Oeuvre" and published several other articles in reputed international journals. He has participated National and International seminars/conferences

Citation: Dr. Venkateswarlu Yesapogu, "The Voice of Indian Women Novelists and their Status in the Contemporary Indian English Literature -A Critical Study", American Research Journal of Humanities and Social Sciences, Volume 2, 2016; pp:1-8

Copyright (C) 2016 Dr. Venkateswarlu Yesapogu. This is an open access article distributed under the Creative Commons Attribution License, which permits unrestricted use, distribution, and reproduction in any medium, provided the original work is properly cited. 